\title{
Pengaruh Permainan Kartu Kasugi terhadap Peningkatan Pengetahuan Perilaku Hidup Bersih dan Sehat pada Siswa
}

\author{
Kristyawan Sutriyanto, ${ }^{1}$ Ardini S. Raksanagara, ${ }^{2}$ Merry Wijaya ${ }^{2}$ \\ ${ }^{1}$ Program Promosi Kesehatan \& Pemberdayaan Masyarakat Dinas Kesehatan Kabupaten Bandung Barat \\ ${ }^{2}$ Departemen Ilmu Kesehatan Masyarakat, Fakultas Kedokteran, Universitas Padjadjaran
}

\begin{abstract}
Abstrak
Penyuluhan kesehatan dengan metode yang menarik dapat meningkatkan pengetahuan perilaku hidup bersih dan sehat. Penelitian ini bertujuan menganalisis pengaruh permainan kartu Kasugi terhadap peningkatan pengetahuan perilaku hidup bersih dan sehat pada siswa Sekolah Dasar. Metode penelitian menggunakan pendekatan Quasi Experimental dengan Non-Equivalent Control Group Design. Subyek penelitian adalah siswa kelas 5 sekolah dasar di Kabupaten Bandung Barat. Data kuantitatif diperoleh dari nilai pretest-posttest pada kelompok eksperimen yang mendapat permainan kartu Kasugi maupun kelompok kontrol dengan ceramah. Hasil analisis dengan uji Repeated Anova menunjukkan terdapat perbedaan bermakna nilai pretest dan posttest pengetahuan setelah siswa mendapat 1 kali permainan kartu Kasugi $(p=0,021)$ dengan kenaikan sebesar 0,62, setelah 2 kali permainan kartu Kasugi $(p=0,001)$ dengan kenaikan 22,24, dan setelah 3 kali permainan kartu Kasugi $(p=0,001)$ dengan kenaikan 32,40. Tidak terdapat perbedaan bermakna peningkatan pengetahuan antara siswa yang mendapat 3 kali permainan kartu Kasugi dengan siswa yang mendapat 3 kali ceramah $(p=0,831)$. Penyuluhan kesehatan melalui permainan kartu Kasugi sebanyak 1 kali atau lebih berpengaruh terhadap peningkatan pengetahuan perilaku hidup bersih dan sehat pada siswa. Penyuluhan kesehatan melalui permainan kartu Kasugi sebanyak 3 kali berpengaruh terhadap peningkatan pengetahuan perilaku hidup bersih dan sehat yang sama dengan siswa yang mendapatkan 3 kali penyuluhan kesehatan melalui metode ceramah.
\end{abstract}

Kata Kunci: Kartu Kasugi, Pengetahuan, Permainan, PHBS

\section{The Influence of Game Card Kasugi Toward the Improvement of Knowledge of Healthy Living Behavior of Student}

\begin{abstract}
Health education with an attractive method can help to improve the knowledge to live clean and healthy behaviors. This study is aimed to analyze the effect of a card game Kasugi toward the improvement of knowledge of clean and healthy behaviors in elementary school students. The research method used is Quasi Experimental approach to the design of Non-Equivalent Control Group Design. Subjects were students in grade 5 elementary school in West Bandung regency. The quantitative data obtained from the value pretest-posttest in the experimental group who received a card game Kasugi or the control group lectures. The results showed a significant difference in the value pretest and posttest knowledge after the students got 1 time the card game Kasugi $(p=0.021)$ with a gain of 0.62, after 2 times the card game Kasugi $(p=0.001)$ with an increase of 22,24, and after 3 times the card game Kasugi $(p=0.001)$ with a gain of 32,40. There was no significant difference improved knowledge among students who scored 3 times the card game Kasugi with 3 times lecture $(p=0.831)$. Health education using card games Kasugi 1 times or more affect the improvement on the knowledge of clean and healthy behaviors in students. Using health education through three times the card game Kasugi with 3 times the lectures provide the same improvement of knowledge of hygienic behavior and healthy.
\end{abstract}

Keywords: Kasugi Cards, Knowledge, Games, PHBS

Korespondensi:

Kristyawan Sutriyanto

Program Promosi Kesehatan \& Pemberdayaan Masyarakat Dinas Kesehatan Kabupaten Bandung Barat Komplek Perkantoran Pemkab. Bandung Barat

Jln. Padalarang - Cisarua km 2 desa Mekargalih Kecamatan Ngamprah

Mobile : 081394115262

Email : kristyawan.sutriyanto@gmail.com 


\section{Pendahuluan}

Program promosi kesehatan Perilaku Hidup Bersih dan Sehat (PHBS) merupakan pendekatan upaya pencegahan penyakit melalui perubahan perilaku individu maupun masyarakat untuk meningkatkan derajat kesehatan. PHBS yang diterapkan dalam kehidupan sehari-hari sangat berpengaruh terhadap kesehatan, karena dapat mencegah risiko timbulnya penyakit, baik penyakit infeksi atau penyakit tidak menular. ${ }^{1}$ Penerapan PHBS dapat memengaruhi tingkat kesehatan individu maupun masyarakat. Individu yang memiliki kebiasaan PHBS akan memiliki risiko yang lebih kecil terkena berbagai penyakit. Penyakit yang berkaitan dengan PHBS diantaranya: diare, kecacingan, penyakit kulit, Infeksi Saluran Pernapasan Akut (ISPA), Demam Berdarah Dengue (DBD) ${ }^{2,3}$

Kaitan PHBS dengan kejadian diare didukung oleh hasil penelitian yang menyatakan bahwa cuci tangan dengan air mengalir dan menggunakan sabun dapat mengurangi jumlah kuman yang ada di tangan.4 Kebiasaan mencuci tangan dengan sabun juga terbukti mampu mengurangi risiko penyakit diare pada anak-anak sebesar $44 \% .^{5}$ Penelitian lain juga menyatakan bahwa kegiatan memberantas jentik nyamuk dengan menguras dan menutup tempat penampungan air dapat menurunkan keberadaan larva Aedes aegypti sehingga berkontribusi dalam menurunkan angka kejadian demam dengue. ${ }^{6}$ Berkaitan dengan perilaku jajan murid sekolah dasar di Indonesia, ditemukan bahwa kebiasaan mengkonsumsi jajanansehatdapatmelindungisiswa daripengaruh bahan makanan yang berbahaya hingga $60 \%{ }^{7}$

Dalam upaya merubah perilaku dibutuhkan pengetahuan dan motivasi. ${ }^{8}$ PHBS yang diajarkan pada anak-anak melalui penyuluhan kesehatan, diharapkan dapat diterapkan pula di lingkungan rumah mereka dan lingkungan sekitarnya. Melihat bahwa anak-anak banyak menghabiskan waktunya di sekolah sebagai tempat menuntut ilmu, diharapkan pula mereka dapat memberi pengertian dan menggugah orangorang disekitarnya tentang pentingnya PHBS. Kurangnya penyuluhan kesehatan tentang PHBS pada siswa sekolah dapat berpengaruh terhadap perilaku dan status kesehatan mereka. Munculnya berbagai penyakit yang sering menyerang anak usia sekolah (6-12 tahun), ternyata umumnya berkaitan dengan PHBS. ${ }^{9}$ Berdasarkan data Susenas tahun 2007 menyebutkan bahwa sekitar $3 \%$ anak-anak mulai merokok sejak kurang dari usia 10 tahun. Persentase perokok tertinggi $(64 \%)$ berada pada kelompok usia remaja $(10-$ 19 tahun). Dan sebagian besar (82\%), penduduk yang berusia 10 tahun ke atas kurang melakukan aktivitas fisik dengan kategori (73\%) kurang bergerak dan $(9 \%)$ tidak terbiasa melakukan aktifitas fisik. ${ }^{10}$ Belum lagi persoalan keamanan makanan yang dijual di sekitar sekolah yang belum menerapkan prinsip-prinsip Hygiene. Bila penyuluhan kesehatan tentang PHBS ini dilakukan dengan baik maka akan mengurangi dampak risiko terjadinya berbagai penyakit yang berkaitan dengan perilaku tidak sehat pada siswa.

Pemberian materi penyuluhan kesehatan lebih mudah tersampaikan jika menggunakan media yang dapat menarik perhatian siswa. Melalui metode yang benar dan penggunaan alat peraga yang tepat sasaran, maka materi yang disampaikan dalam penyuluhan kesehatan akan mudah diterima, dicerna dan diserap oleh sasaran. Penyampaian materi pendidikan akan lebih efektif bila disampaikan dalam suasana yang menyenangkan dan menggunakan metode yang menarik perhatian siswa. ${ }^{11}$ Penyuluhan kesehatan dengan permainan edukatif lebih menyenangkan dibanding penyuluhan dengan metode pengajaran di kelas maupun ceramah. ${ }^{12}$ Diharapkan kegiatan penyuluhan kesehatan dengan menggunakan metode permainan akan menimbulkan ketertarikan siswa sehingga dengan mudah dapat mengerti serta mampu mengingat pesan kesehatan yang disampaikan.

Melalui penelitian ini penulis mengembangkan sebuah metode penyuluhan kesehatan melalui permainan kartu kuartet sunugiras atau disingkat Kasugi. Sunugiras berasal dari bahasa sansekerta yaitu Sunu yang berarti anak dan Giras yang berarti sehat. ${ }^{13}$ Permainan kartu Kasugi merupakan model baru yang belum pernah digunakan secara luas sebagai metode penyuluhan kesehatan khususnya bagi anak usia sekolah. Kartu Kasugi berisi pesan-pesan tentang perilaku hidup bersih dan sehat yang diadopsi dari indikator PHBS sekolah. Satu set permainan kartu Kasugi terdiri dari 40 buah kartu yang terbagi dalam 10 topik berkaitan dengan PHBS sekolah dan masing-masing topik terdiri dari 4 subtopik yang merupakan penjelasan dari topik diatasnya. Pemberian penyuluhan kesehatan melalui metode permainan bertujuan untuk meningkatkan pengetahuan siswa untuk berperilaku sehat dengan suasana yang menyenangkan. Permainan kartu Kasugi dapat digunakan tidak hanya sebatas pada anak di sekolah, namun dapat pula digunakan sebagai media penyuluhan kesehatan bagi anak-anak secara umum.

\section{Metode}

Penelitian dilaksanakan di Kabupaten Bandung Barat mulai Februari hingga April 2016. 
Penelitian ini merupakan penelitian kuantitatif yang menggunakan pendekatan Quasi Experiment dengan rancangan Non-Equivalent Control Group Design dengan pretest and posttest. Kelompok eksperimen dalam penelitian mendapatkan perlakuan pemberian penyuluhan kesehatan melalui permainan kartu Kasugi, sedangkan kelompok kontrol mendapatkan penyuluhan kesehatan melalui metode ceramah. Subyek dalam penelitian ini adalah siswa kelas 5 dengan jumlah 43 orang untuk setiap kelompok.

Kriteria inklusi pada penelitian ini diantaranya siswa berusia 10-12 tahun, tercatat sebagai siswa kelas 5 SD di Kabupaten Bandung Barat, serta bersedia menjadi responden. Kriteria ekslusi diantaranya adalah responden yang tidak hadir pada saat penelitian berlangsung, tidak mengisi kuesioner dengan lengkap dan benar sesuai panduan, atau tidak mengikuti proses penelitian hingga selesai. Data kuantitatif berupa nilai pretest dan posttest dari kuesioner pengetahuan. Kuesioner untuk mengukur tingkat pengetahuan terdiri dari 10 pertanyaan, dimana masingmasing pertanyaan memiliki 6 pilihan jawaban dan diantaranya ada 3 jawaban yang benar. Siswa yang menjadi subjek wajib memilih tiga pilihan jawaban untuk masing-masing pertanyaan. Penilaian untuk mengukur tingkat pengetahuan menggunakan sistem skor, dimana jawaban yang benar diberi nilai 1 dan jawaban yang salah diberi nilai 0 . Cara menghitung nilai pengetahuan masing-masing siswa adalah dengan membagi total skor jawaban yang benar dibagi skor ideal atau 30 kemudian dikalikan 100. Adapun rumus untuk menentukan skor pengetahuan pada masing-masing siswa adalah sebagai berikut:

$$
\mathrm{S}={ }_{\mathrm{SI}}^{\mathrm{SB}} \mathrm{X} 100
$$

Keterangan:

S : Total Skor

SB : Skor Jawaban Benar

SI : Skor Ideal

Setelah melalui uji normalitas data nilai pretest, posttest 1, posttest 2, serta posttest 3 selanjutnya dianalisis secara statistik dengan uji Repeated Anova, sedangkan uji beda peningkatan pengetahuan setelah siswa mendapat 3 kali permainan kartu Kasugi dan 3 kali ceramah dengan uji Independent T Test.

\section{Hasil}

Tingkat Pengetahuan Siswa Setelah Mendapat Permainan Kartu Kasugi; Perbedaan tingkat pengetahuan sebelum dan sesudah mendapatkan penyuluhan kesehatan melalui permainan kartu Kasugi, karena data berdistribusi normal nilai pretest, posttest pertama, posttest kedua, dan posttest ketiga kemudian dianalisis dengan uji Repeated Anova.

Hasil penelitian menunjukan bahwa nilai rerata pretest siswa yang mendapat permainan kartu Kasugi sebesar 43,41.

\section{Tabel 1 Rancangan Penelitian}

\begin{tabular}{|c|c|c|c|c|c|c|c|}
\hline $\begin{array}{l}\text { Kelompok Eksperimen Permainan } \\
\text { Kartu Kasugi }\end{array}$ & $\mathrm{O}^{1}$ & $X^{1}$ & $\mathrm{O}^{2}$ & $X^{2}$ & $\mathrm{O}^{3}$ & $X^{3}$ & $\mathrm{O}^{4}$ \\
\hline $\begin{array}{l}\text { Kelompok Kontrol Metode } \\
\text { Ceramah }\end{array}$ & $\mathrm{O}^{5}$ & $X^{4}$ & $\mathrm{O}^{6}$ & $X^{5}$ & $\mathrm{O}^{7}$ & $X^{6}$ & $\mathrm{O}^{8}$ \\
\hline
\end{tabular}

Keterangan:

O1 : Pretest pada kelompok eksperimen untuk mengetahui tingkat pengetahuan awal

O2 : Posttest pada kelompok eksperimen setelah mendapat 1 kali permainan kartu kasugi

O3 : Posttest pada kelompok eksperimen setelah mendapat 2 kali permainan kartu kasugi

O4 : Posttest pada kelompok eksperimen setelah mendapat 3 kali permainan kartu kasugi

O5 : Pretest pada kelompok kontrol untuk mengetahui tingkat pengetahuan awal siswa

O6 : Posttest pada kelompok kontrol setelah mendapat 1 kali ceramah

O7 : Posttest pada kelompok kontrol setelah mendapat 2 kali ceramah

O8 : Posttest pada kelompok kontrol setelah mendapat 3 kali ceramah

$\mathrm{X} 1$ : Pemberian permainan kartu kasugi yang pertama

$\mathrm{X} 2$ : Pemberian permainan kartu kasugi yang kedua

$\mathrm{X} 3$ : Pemberian permainan kartu kasugi yang ketiga

$\mathrm{X} 4$ : Pemberian ceramah yang pertama

$\mathrm{X} 5$ : Pemberian ceramah yang kedua

$\mathrm{X} 6$ : Pemberian ceramah yang ketiga 
Kristyawan Sutriyanto : Pengaruh Permainan Kartu Kasugi terhadap Peningkatan Pengetahuan Perilaku Hidup Bersih dan Sehat pada Siswa
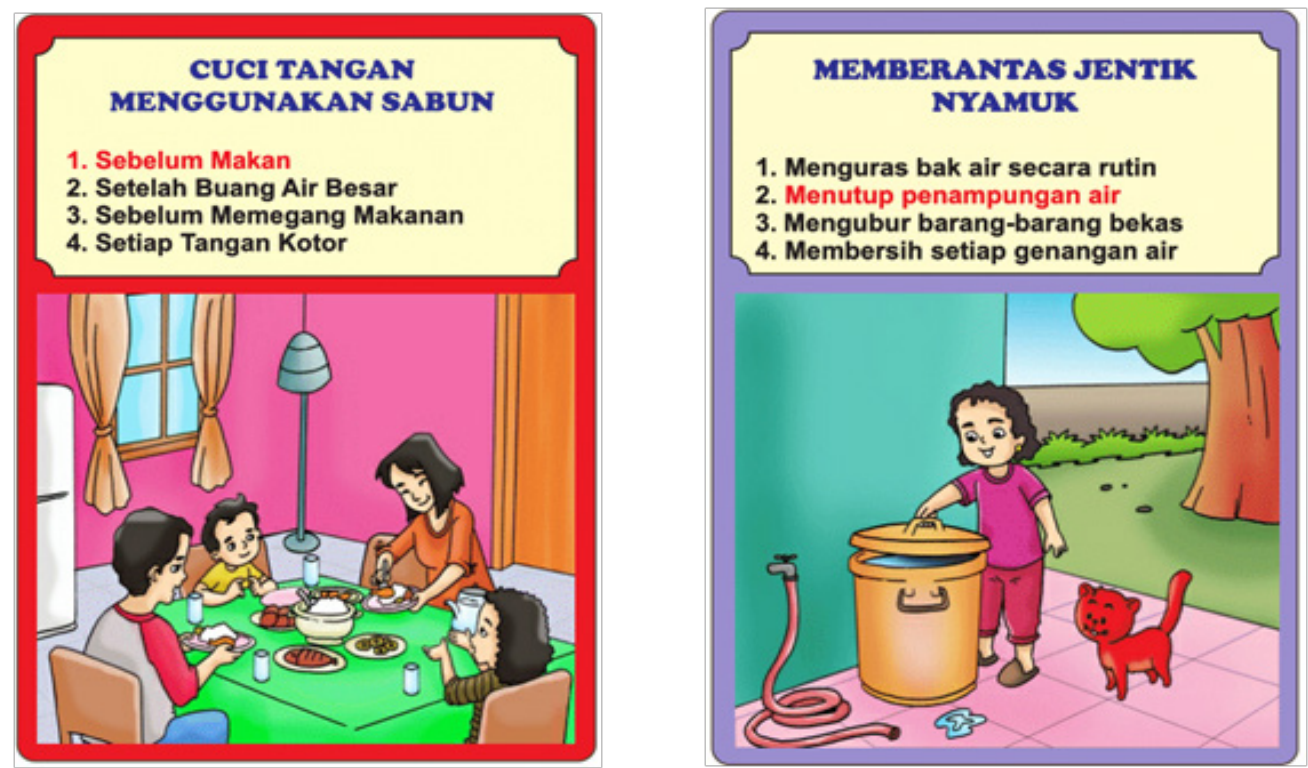

\section{Gambar 1 Contoh Kartu Kasugi}

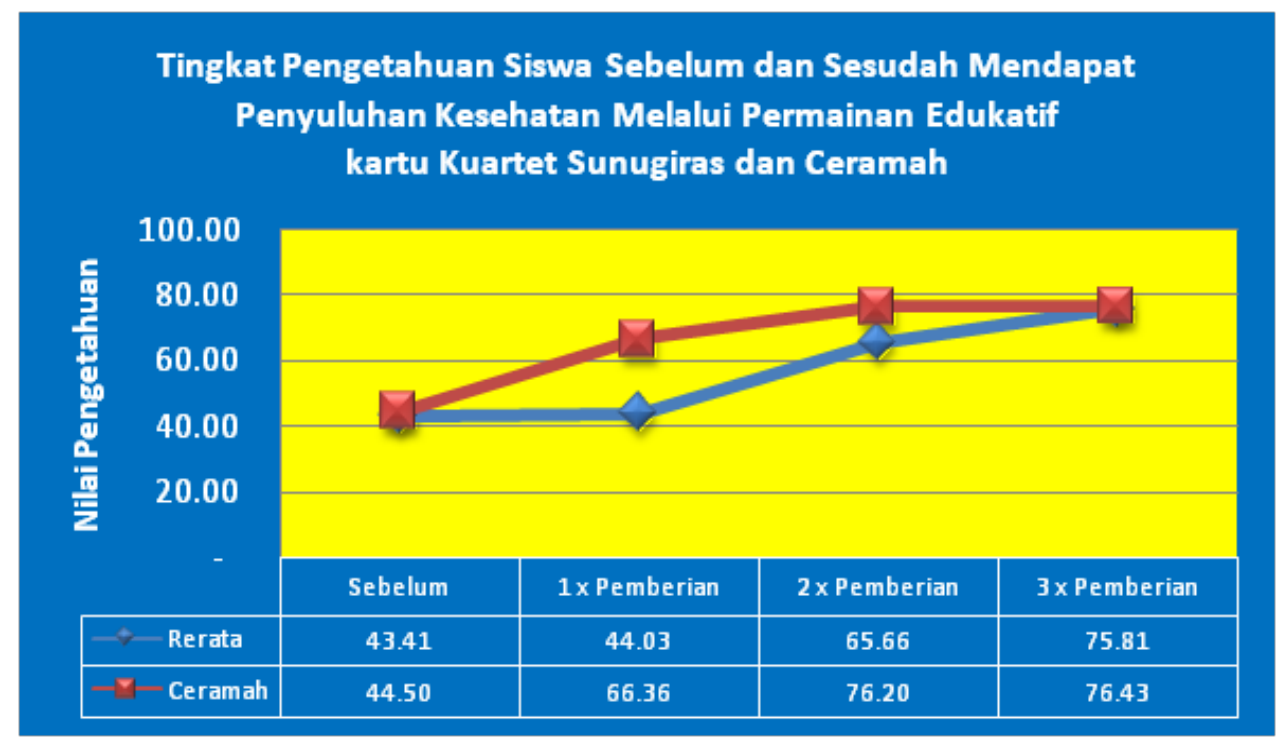

\section{Gambar 2 Tingkat Pengetahuan Siswa yang Mendapat Penyuluhan Kesehatan Melalui Permainan kartu Kasugi}

Terdapat peningkatan nilai rerata pengetahuan setelah siswa mendapat 1 kali permainan kartu Kasugi menjadi 44,03, setelah 2 kali permainan kartu Kasugi menjadi 65,66, dan setelah 3 kali permainan kartu Kasugi sebesar 75,81.

Berdasarkan hasil analisis statistik dapat diketahui bahwa terdapat peningkatan pengetahuan antara nilai pretest dan posttest setelah siswa mendapat 1 kali permainan kartu Kasugi sebesar 0,62 $(p=0,021)$. Terdapat peningkatan pengetahuan setelah siswa mendapat 2 kali permainan kartu Kasugi sebesar 22,24 $(p=0,001)$, dan terdapat peningkatan pengetahuan setelah siswa mendapat 3 kali permainan kartu Kasugi sebesar 32,40 $(p=0,001)$.

Berdasarkan hasil analisis statistik dapat diketahui bahwa terdapat peningkatan pengetahuan antara nilai pretest dan posttest setelah siswa mendapat 
Kristyawan Sutriyanto : Pengaruh Permainan Kartu Kasugi terhadap Peningkatan Pengetahuan Perilaku Hidup Bersih dan Sehat pada Siswa

Tabel 2 Tingkat Pengetahuan Siswa Setelah Mendapat Permainan Kartu Kasugi

\begin{tabular}{|c|c|c|c|}
\hline (I) Nilai & (J) Nilai & Beda Rerata (I-J) & Nilai $P$ \\
\hline \multirow[t]{3}{*}{ Pretest } & Posttest 1 kali Permainan Kartu Kasugi & 0,62 & 0,021 \\
\hline & Posttest 2 kali Permainan Kartu Kasugi & 22,24 & 0,001 \\
\hline & Posttest 3 kali Permainan Kartu Kasugi & 32,40 & 0,001 \\
\hline
\end{tabular}

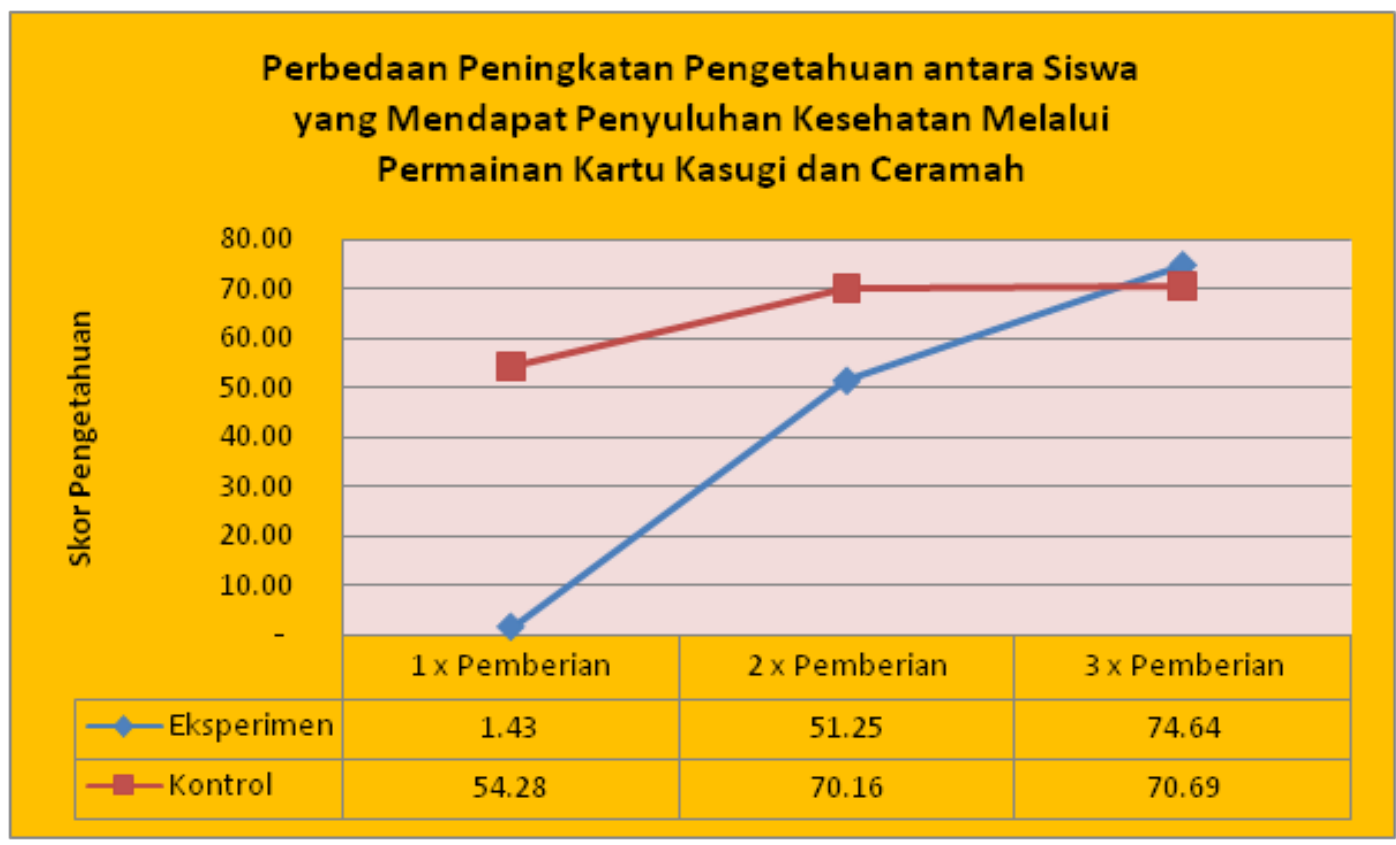

Gambar 3 Perbandingan Peningkatan Pengetahuan antara Siswa yang Mendapat Penyuluhan Kesehatan Melalui Permainan kartu Kasugi dan Ceramah

1 kali permainan kartu Kasugi sebesar 0,62 $(p=0,021)$. Terdapat peningkatan pengetahuan setelah siswa mendapat 2 kali permainan kartu Kasugi sebesar 22,24 $(p=0,001)$, dan terdapat peningkatan pengetahuan setelah siswa mendapat 3 kali permainan kartu Kasugi sebesar 32,40 $(p=0,001)$.

Perbedaan Peningkatan Pengetahuan antar Siswa yang Mendapat 3 kali Permainan Kartu Kasugi dengan 3 kali Ceramah; Uji perbedaan peningkatan pengetahuan bertujuan membandingkan persentase peningkatan pengetahuan antara kelompok eksperimen yang mendapat 3 kali permainan kartu kuartet sunugiras dengan kelompok kontrol yang mendapat 3 kali ceramah. Persentase peningkatan pengetahuan diperoleh dengan menggunakan rumus sebagai berikut:

$$
\mathrm{P}=\frac{\text { Posttest }- \text { Pretest }}{\text { Pretest }} \mathrm{X} 100
$$

Keterangan :

P : Peningkatan Pengetahuan

Pretest : Nilai Sebelum Mendapat Perlakuan Posttest : Nilai Sesudah Mendapat Perlakuan

Pada kelompok siswa yang mendapat 3 kali permainan kartu Kasugi mengalami peningkatan persentase pengetahuan lebih tinggi $(74,64 \%)$ dibandingkan kelompok siswa yang mendapatkan 3 kali ceramah (70,69\%). Dari hasil analisis statistik dengan uji Independent T Test didapatkan hasil nilai $p=0,328$, sehingga dapat disimpulkan tidak ada perbedaan yang signifikan antara siswa yang mendapat penyuluhan kesehatan melalui 3 kali permainan kartu Kasugi dengan siswa yang mendapatkan 3 kali ceramah.

\section{Pembahasan}

Hasil penelitian diatas menunjukkan bahwa terdapat pengaruh permainan kartu Kasugi yang 
diberikan minimal 1 kali terhadap peningkatan pengetahuan perilaku hidup bersih dan sehat pada siswa sekolah dasar di Kabupaten Bandung Barat. Hal tersebut sejalan dengan hasil penelitian di Inggris yang dilakukan oleh Blakely,dkk yang menyebutkan bahwa permainan edukatif terbukti efektif dalam mendukung pembelajaran, terutama untuk meningkatkan pengetahuan. ${ }^{14}$

Hasil penelitian ini juga sejalan dengan hasil penelitian di India yang dilakukan oleh Akshatha Nayak, dkk yang menyebutkan bahwa pembelajaran berbasis permainan merupakan metode penyuluhan kesehatan yang efektif untuk meningkatkan pengetahuan anak-anak sekolah dasar. ${ }^{15}$ Bermain mengandung aspek menyenangkan dan menimbulkan kegembiraan sehingga dapat menimbulkan minat anak untuk ikut serta. Kegembiraan yang ditimbulkan dalam proses belajar dapat membantu pemahaman siswa atas materi yang diterima. Georgi Lazanov menyebutkan bahwa proses belajar yang menyenangkan akan "membangun sugesti positif" atau dengan arti lain situasi belajar menyenangkan akan memberikan hasil belajar yang lebih optimal. ${ }^{16}$

Kartu Kasugi merupakan media yang berisi pesan dan informasi tentang perilaku hidup bersih dan sehat. Pesan yang ada dalam kartu kasugi didukung berbagai gambar yang menarik dan sesuai dengan topik di masing-masing kartu. Metode penyuluhan kesehatan yang menarik dan menciptakan situasi menyenangkan menjadi faktor pendukung timbulnya keinginan untuk memainkannya. Dalam permainan kartu Kasugi, setiap peserta berusaha untuk mengumpulkan sebanyak mungkin set kartu dengan topik yang sama. Oleh Karen itu, dengan memainkan permainan kartu Kasugi, siswa akan terpapar oleh materi tentang PHBS yang ada dalam topik dan subtopik di setiap kartu Kasugi. Atas dasar uraian dan data diatas menunjukkan bahwa permainan kartu kasugi dapat digunakan sebagai salah satu upaya untuk meningkatkan pengetahuan siswa dalam berperilaku hidup bersih dan sehat.

Hasil analisis selanjutnya menyebutkan bahwa setelah siswa pada kelompok eksperimen dan kontrol mendapatkan perlakuan, keduanya sama-sama mengalami peningkatan pengetahuan, dimana kelompok yang mendapatkan 3 kali permainan kartu Kasugi mengalami peningkatan rerata pengetahuan lebih tinggi yakni sebesar 32,40 dibandingkan kelompok yang mendapatkan 3 kali ceramah dengan peningkatan rerata pengetahuan sebesar 31,94. Hasil dari uji beda menyebutkan bahwa tidak terdapat perbedaan yang bermakna peningkatan pengetahuan antara siswa yang mendapat 3 kali penyuluhan kesehatan melalui metode permainan kartu Kasugi dengan siswa yang mendapat 3 kali penyuluhan kesehatan melalui metode ceramah. Berdasarkan hasil analisis tersebut dapat disimpulkan bahwa baik metode permainan kartu kasugi maupun ceramah setelah diberikan sebanyak 3 kali samasama meningkatkan pengetahuan.

Hasil diatas memberikan dasar bahwa metode penyuluhan kesehatan melalui permainan kartu Kasugi maupun ceramah sama-sama memiliki pengaruh untuk meningkatkan pengetahuan siswa tentang PHBS. Namun penyuluhan kesehatan melalui metode permainan kartu Kasugi memiliki kelebihan dibandingkan dengan metode ceramah, diantaranya praktis, mudah dalam penyajiannya, mudah dimainkan, mudah disimpan, dapat digunakan untuk kelompok besar atau kecil dan siswa ikut aktif dalam penyajiannya. ${ }^{17}$ Permainan kartu Kasugi termasuk sebuah metode penyuluhan kesehatan yang praktis karena untuk satu kali permainan hanya membutuhkan waktu antara 20 hingga 30 menit. Praktis karena tidak harus menggunakan waktu khusus, bisa dilakukan pada jam istirahat ataupun pada waktu luang yang dimiliki oleh anak-anak. Selain hanya memerlukan waktu yang cukup singkat, permainan kartu Kasugi tidak memerlukan alat bantu lain sehingga memudahkan dalam penyajian. Hasil pengamatan selama penelitian, penulis mendapatkan bahwa sekitar 92\% siswa telah mengetahui dan memahami bagaimana cara bermain kartu kuartet sehingga tidak sulit untuk memainkan permainan kartu Kasugi. Kelebihan lain dari kartu Kasugi adalah karena ukurannya yang cukup kecil sehingga mudah untuk disimpan.

Selain kelebihan-kelebihan yang sudah disebutkan diatas, ada satu kelebihan dari metode permainan kartu kasugi yang tidak dimiliki oleh metode ceramah, yaitu proses penyampaian pesan tidak harus tergantung kepada petugas kesehatan atau guru, karena permainan kartu Kasugi dapat dimainkan secara mandiri. Karena sifatnya yang mandiri, permainan kartu kasugi dapat dimainkan sesering mungkin. Semakin sering dimainkan, akan semakin sering pula siswa terpapar pesan tentang PHBS sehingga berpengaruh terhadap pengetahuannya.

Penelitian ini telah memberikan gambaran tentang pengaruh permainan kartu Kasugi terhadap peningkatan pengetahuan perilaku hidup bersih dan sehat. Namun demikian penelitian ini masih memiliki banyak keterbatasan, diantaranya adalah Penelitian ini baru membahas pengaruh permainan kartu Kasugi terhadap peningkatan pengetahuan perilaku hidup bersih dan sehat, belum membahas pengaruhnya terhadap perubahan perilaku hidup bersih dan sehat. Hal tersebut karena untuk mengukur perubahan perilaku memerlukan waktu yang relatif lama 
sedangkan penulis memiliki keterbatasan waktu penelitian; Di beberapa sekolah penulis mengalami kesulitan mendapatkan tempat yang memenuhi kriteria untuk pelaksanaan perlakuan pada kelompok eksperimen. Hal tersebut karena sekolah hanya menyediakan satu ruang kelas yang dapat digunakan untuk melaksanakan permainan kartu Kasugi, sehingga suasana ruangan terkadang berisik dan kemungkinan mengganggu konsentasi siswa dalam memahami isi pesan dalam permainan tersebut.

Simpulan, pemberian penyuluhan kesehatan melalui permainan kartu Kasugi sebanyak 1 kali atau lebih berpengaruh terhadap peningkatan pengetahuan perilaku hidup bersih dan sehat pada siswa sekolah dasar. Siswa yang mendapat permainan kartu Kasugi sebanyak 3 kali mengalami peningkatan pengetahuan sebesar $74,64 \%$ dan siswa yang mendapat ceramah sebanyak 3 kali mengalami peningkatan sebesar $70,69 \%$. Hasil analisis statistik diketahui bahwa tidak terdapat perbedaan yang bermakna peningkatan pengetahuan perilaku hidup bersih dan sehat antara siswa yang mendapatkan 3 kali penyuluhan kesehatan melalui permainan kartu Kasugi dengan metode ceramah.

Saran, Permainan edukatif kartu kuartet sunugiras dapat digunakan secara luas sebagai metode penyuluhan kesehatan tidak hanya terbatas pada siswa kelas 5 sekolah dasar. Perlu untuk menerjemahkan topik yang ada pada kartu Kasugi ke dalam berbagai bahasa daerah, agar lebih mudah dipahami oleh anak-anak.

\section{Daftar Pustaka}

1. Raksanagara, S.A. Perilaku Hidup Bersih dan Sehat Sebagai Determinan Kesehatan yang Penting pada Tatanan Rumah Tangga di Kota Bandung. JSK. 2015;1(1): hlm. 31; 33

2. Fitriani D., Pengaruh Edukasi Sebaya Terhadap Perilaku Hidup Bersih dan Sehat (PHBS) pada AgregatAnak Usia Sekolah yang Beresiko Kecacingan di Desa Baru Kecamatan Manggar Belitung Timur. 2011 [diunduh 22 Oktober 2015]. Tersedia dari : http://lib. ui.ac. id/file? file $=$ digital $/ 20280655-\mathrm{T} \% 20$ Dianita\%20Fitriani.pdf.

3. Solehati T., Susilawati S., Lukman M., Pengaruh Edukasi PHBS Terhadap Pengetahuan dan Skill Siswa Sekolah Dasar. 2014 [diunduh 29 Oktober 2015]. Tersedia dari : http://www.pustaka.unpad.ac.id/wpcontent/04/3-Pengaruh-Edukasi-PHBS.pdf

4. Rahmawati, J.F., Triyana, S.Y. Perbandingan Angka Kuman Pada Cuci Tangan Dengan Beberapa Bahan Sebagai Standarisasi Kerja di Laboratorium Mikrobiologi Fakultas Kedokteran Universitas Islam Indonesia. Volume 5. Jakarta. Logika; 2008; [diunduh 26 Juli 2015]. hlm.36-42. Tersedia dari : http://www.uii.ac.id.

5. Cahyanto, S. Gaya Hidup dan Penyakit Modern. Yogyakarta: Kanisius; 2008. hlm. .

6. Jaya M.D., Ibrahim E., Anwar. Hubungan Pemberantasan Sarang Nyamuk (PSN) DBD Dengan Keberadaan Larva Aedes Aegypti di Wilayah Endemis DBD Kelurahan Kassi Kassi Kota Makasar.FKM Unhas. Makasar; 2013 [diunduh 27 Juli 2015]. Tersedia dari : http://www.repository.unhas.ac.id.

7. Suci T.S.E., Gambaran Perilaku Jajan Murid Sekolah Dasar di Jakarta, Volume 1. No.1, 29-38. Jurnal Psikobuana: Jakarta; 2005 [diunduh 26 Juli 2015]; Tersedia dari: http:// www.psikobuana.com.

8. Elder JP, Hovell M, Mayer J, et al. Motivating Health Behavior. New York, NY: Delmar, 1994, 128-147.

9. Departemen Kesehatan Republik Indonesia. Pusat Promosi Kesehatan, Promosi Kesehatan Sekolah. Jakarta : Departemen Kesehatan RI. 2011.hlm.

10. Badan Pusat statistik (BPS), Survei Sosial Ekonomi Nasional (Susenas). Jakarta : Badan Penelitian dan Pengembangan Kesehatan; 2007.

11. Helmi.D.R, Zaman S. 12 Permainan untuk Meningkatkan Intelegensi Anak. Jakarta: Visi Media Pustaka; 2014.

12. Baranowski T., Buday R., Thompson D., Lyons E.J., Lu A.S., Baranowski J., Developing Games for Health Behavior Change: Getting Started. 2013 [diunduh 30 September 2015]; Vol.2, ( 4) Tersedia dari : Pubmed. http://www.ncbi.nlm.nih.gov.

13. Wiktionary. Kamus bahasa Sanskerta - bahasa Indonesia. 2015. [diundur 27 November 2015]. Tersedia dari: https:// id.wiktionary.org/wiki/Wiktionary:Kamus bahasa_Sanskerta_\%E2\%80\%93_bahasa Indonesia.

14. Blakely G1, Skirton H, Cooper S, Allum P, Nelmes P. Use of educational games in the health professions: a mixed-methods study of educators' perspectives in the UK. UK; 2010. [diunduh 24 Oktober 2015]; 12(1):27-32. Tersedia dari: Pubmed. http://www.ncbi.nlm. nih.gov/pubmed/20487322.

15. Nayak A., Pai S.M., Satish Y., "Effectiveness of game based learning on knowledge of health promotion among primary school children - a quasi experimental study", International Journal of Current Research 7, (9), 20658-20661. 2015 [diunduh 2 Oktober 

pada Siswa

2015]. Tersedia dari : http://www.journalcra. com.

16. DePorter, Bobby, Mark Reardon dan Sarah Singer. Quantum Teaching. Nourie. Terjemahan Edisi2, cetakanke-1.Penerjemah : Ary Nilandari. Bandung: Kaifa; 2010.
17. Universitas Esa Unggul. Modul Metode dan Media Promosi Kesehatan Sarapan pagi. Program Studi Ilmu Gizi: 2015 [diunduh 29 November 2015]. Tersedia dari: http://digilib. esaunggul.ac.id/public/UEU-Undergraduate5778-Modul.pdf. 